\title{
Phorbol esters dPPA/dPA promote furin expression involving transcription factor CEBP $\beta$ in neuronal cells
}

\author{
Jing-Si Zha ${ }^{1, *}$, Bing-Lin Zhu ${ }^{1,}{ }^{*}$, Lu Liu ${ }^{1}$, Yu-Jie Lai ${ }^{1}$, Yan Long $^{1}, X$ Xiao-Tong Hu ${ }^{1}$, Xiao- \\ Juan Deng ${ }^{1}$, Xue-Feng Wang ${ }^{1}$, Zhen Yan ${ }^{2}$ and Guo-Jun Chen ${ }^{1}$ \\ ${ }^{1}$ Department of Neurology, The First Affiliated Hospital of Chongqing Medical University, Chongqing Key Laboratory of \\ Neurology, Chongqing 400016, China \\ ${ }^{2}$ Department of Physiology and Biophysics, State University of New York at Buffalo, Buffalo, NY, 14214, USA \\ *These authors contributed equally to this work
}

Correspondence to: Guo-Jun Chen, email: woodchen2015@163.com

Keywords: furin, $d P P A / d P A, C E B P \beta, E R K, P I 3 K$

Received: December 20, $2016 \quad$ Accepted: June 10, 2017 Published: June 19, 2017

Copyright: Zha et al. This is an open-access article distributed under the terms of the Creative Commons Attribution License 3.0 (CC BY

3.0), which permits unrestricted use, distribution, and reproduction in any medium, provided the original author and source are credited.

\section{ABSTRACT}

Using high-throughput small molecule screening targeting furin gene, we identified that phorbol esters dPPA (12-Deoxyphorbol 13-phenylacetate 20-acetate) and dPA (12-Deoxyphorbol 13-acetate) significantly increased furin protein and mRNA expression in SH-SY5Y cells. This effect was prevented by PKC (protein kinase C) inhibitor calphostin C but not Ro318220, suggesting that the C1 domain, rather than the catalytic domain of PKC plays an important role. Luciferase assay revealed that nucleotides -7925 to -7426 were sufficient to mediate dPPA/dPA enhancement of furin P1 promoter activity. RNA interference of transcriptional factors CEBP (CCAAT/enhancer-binding protein $\beta$ ) and GATA1 revealed that knockdown of CEBPB significantly attenuated the effect of dPPA on furin expression. Pharmacological inhibition of ERK and PI3K but not TGF $\beta$ receptor diminished the up-regulation of furin by dPPA. These results suggested that in neuronal cells, transcriptional activation of furin by dPPA/dPA may be initiated by $\mathrm{C} 1$ domain containing proteins including PKC; the intracellular signaling involves ERK and PI3K and transcription factor CEBPB.

\section{INTRODUCTION}

Furin is one of the proprotein convertases (PCs) [1], which are involved in the proteolysis of precursor proteins, including growth factors and hormones, receptors, and matrix metalloproteinases [2, 3]. Furin knockout mice are unable to survive due to cardiac developmental defects at 10.5 embryonic days [4]. Evidence has suggested that furin plays important role in cancer and infectious diseases [4, 5].

In the nervous system, furin promotes differentiation and collateral formation of nematode sensory neurons $[6,7]$. The wide spectrum of substrates suggests that furin may be important in neuronal functions. For instance, furin catalyzes pro-BDNF (brain-derived neurotrophic factor) and pro-NGF (nerve growth factor) into corresponding mature forms [8, 9]. While mature BDNF/NGF plays critical role in the development and survival of neurons $[10,11]$, pro-BDNF inhibits synaptic plasticity and proNGF promotes apoptosis $[12,13]$. Dysfunction of BDNF is associated with depression, schizophrenia, cerebral trauma and Alzheimer's disease (AD) [14]. Another important substrate of furin is pro-ADAM10 (A disintegrin and metalloproteinase domain-containing protein 10), the $\alpha$-secretase that is closely associated with AD pathology $[15,16]$. Interestingly, furin protein levels are significantly decreased in the brain of AD patients and animal models [17]. It is unclear how furin is regulated in neuronal cells. Using high-throughput small molecules screening, we found that phorbol esters PMA (phorbol 12-myristate 13-acetate), PDBu (phorbol 12, 13-dibutyrate), dPA (12-deoxyphorbol 13-acetate) and dPPA (12-deoxyphorbol 
13-phenylacetate 20-acetate), significantly increased furin luciferase activity. In this study, we found that dPPA and dPA that are not carcinogenic, could increase the expression of furin in neuronal cells. This effect was prevented by PKC inhibitor calphostin $\mathrm{C}$. We further showed that transcription factor CEBP $\beta$ and ERK/PI3K signaling pathways were involved in this regulation.

\section{RESULTS}

\section{dPPA/dPA promoted furin expression}

SH-SY5Y cells stably expressing furin $\mathrm{P} 1$ promoter were seeded onto 384-well plates (3000 cells per well) for $24 \mathrm{~h}$ [18], and were treated with 6990 small molecules provided by the Chinese National Academy (Shanghai, China) at a concentration of $10 \mu \mathrm{M}$ for $24 \mathrm{~h}$. Luciferase assay revealed that the four phorbol esters PMA (phorbol 12-myristate 13-acetate), PDBu (phorbol 12, 13-dibutyrate), dPA (12-deoxyphorbol 13-acetate) and dPPA (12-deoxyphorbol 13-phenylacetate 20-acetate) significantly increased luciferase activity (Figure 1A, Supplementary Figure 1). $10 \mu \mathrm{M}$ of these drugs did not interfere with the viability in both SH-SY5Y and HEK293 cells (Figure 1B and 1C). Since PMA and PDBu may induce carcinogenesis [19], we then selected dPA and IPPA that have been proved as antineoplastic agents [20, 21], for further study. We first assessed the effect of dPA or dPPA on furin protein expression in $\mathrm{SH}-$ SY5Y cells. Dose response analysis showed that the best concentration of dPA or dPPA for furin enhancement was $0.2 \mu \mathrm{M}$ (Figure 1D and 1E), which was chosen throughout the study. In addition to SH-SY5Y cells, HEK293 cells also exhibited significantly increased furin protein and mRNA after dPA/dPPA treatment (Figure $1 \mathrm{~F}$ and $1 \mathrm{G}$ ). Similar results were found in rat primary cortical neurons (Figure 1H and 1I). These results indicated that dPA/dPPA effectively enhanced furin transcription in neuronal cells.

\section{Different effect of PKC inhibitors on IPPA/dPA regulation of furin expression}

Phorbol esters are known to be PKC activators $[22,23]$. To test whether PKC may be involved in furin expression, we first assessed the effect of Ro318220 (a PKC inhibitor), which competes with PKC for ATP binding $[19,24]$. SH-SY5Y cells were treated with $10 \mu \mathrm{M}$ Ro318220 in the absence or presence of $0.2 \mu \mathrm{M}$ dPPA or dPA for $72 \mathrm{~h}$. Figure 2A showed that Ro318220 alone had no effect on furin expression compared to control, and the inhibition of PKC by Ro318220 did not affect the up-regulation of furin induced by dPPA or dPA. Next, we tested the effect of another PKC inhibitor calphostin $\mathrm{C}$ that competitively inhibits phorbol ester binding to the $\mathrm{C} 1$ domain $[19,25]$. We found that $0.5 \mu \mathrm{M}$ calphostin $\mathrm{C}$ alone significantly reduced the basal furin protein level compared to control. In the presence of calphostin $\mathrm{C}$, the induction of furin by dPPA or dPA was diminished (Figure 2B, $P<0.01$ ).

To further validate the results of Western blotting, we investigated whether mRNA levels of furin were analogously affected by Ro318220 or calphostin C. Similarly, Ro318220 did not affect the basal level and dPPA/dPA-induced upregulation of furin mRNA in SH-SY5Y cells (Figure 2C). In contrast, calphostin C significantly reduced the basal level of furin mRNA and blocked the induction of furin mRNA by dPPA or dPA in SH-SY5Y cells (Figure 2D). In addition, as expected, calphostin C rather than Ro318220 inhibited the upregulation of furin protein induced by dPPA or dPA in HEK293 cells (Figure 2E). These results suggested that $\mathrm{PKC} \mathrm{C} 1$ domain, rather than the kinase activity, was involved in $\mathrm{dPPA} / \mathrm{dPA}$ regulation of furin expression.

\section{Nucleotides $\mathbf{- 7 9 2 5}$ to $\mathbf{- 7 4 2 6}$ were sufficient to mediate dPPA/dPA enhancement of furin}

To further identify the core elements that are responsible for $\mathrm{dPPA} / \mathrm{dPA}$ regulation of furin, the different sequentially deleted 5'-flanking regions of furin P1 promoter (pGL4.17-furin-P1-A, pGL4.17-furin-P1-B, pGL4.17-furin-P1-C, pGL4.17-furin-P1-E and pGL4.17furin-P1-G) were generated (Figure 3A). SH-SY5Y cells were transiently transfected with each truncated promoter for $24 \mathrm{~h}$ and then were treated with $0.2 \mu \mathrm{M}$ dPPA or dPA for $24 \mathrm{~h}$. We found that except P1-E, all promoter fragments responded well to dPPA, all of which contained P1-B fragment sequence (nucleotides -7925 to -7426 , Figure 3B). Similarly, in dPA treated cells, P1-B luciferase activity was significantly increased (Figure 3C). These results indicated that nucleotides -7925 to -7426 in furin $\mathrm{P} 1$ promoter were sufficient to mediate $\mathrm{dPA} / \mathrm{dPPA}$-induced expression of furin.

\section{dPPA/dPA regulation of furin involved transcription factor CEBP $\beta$}

It is reported that furin P1 promoter has GATA1 element and can be trans-activated by transcription factor CEBP $\beta$ (CCAAT/enhancer-binding protein $\beta$ ) $[26,27]$. To test whether direct manipulation of $C E B P \beta$ or GATA1 may affect furin expression induced by dPPA, we assessed the effect of dPPA/dPA in SH-SY5Y cells transiently transfected with $C E B P \beta$ or GATA1 siRNA. As shown in Figure $4 \mathrm{~A}$ and $4 \mathrm{~B}, C E B P \beta$ siRNA led to dramatically decreased CEBP $\beta$ protein expression. CEBP $\beta$ knockdown did not reduce the basal level of furin protein but diminished dPPA/dPA-induced enhancement of furin in SH-SY5Y cells (Figure 4A and 4B). Interestingly, dPA/ dPPA seemed to increase CEBP $\beta$ transcription in SHSY5Y cells, as revealed by qPCR (Figure 4C). In GATA1 siRNA transfected cells, the basal level of furin was not 

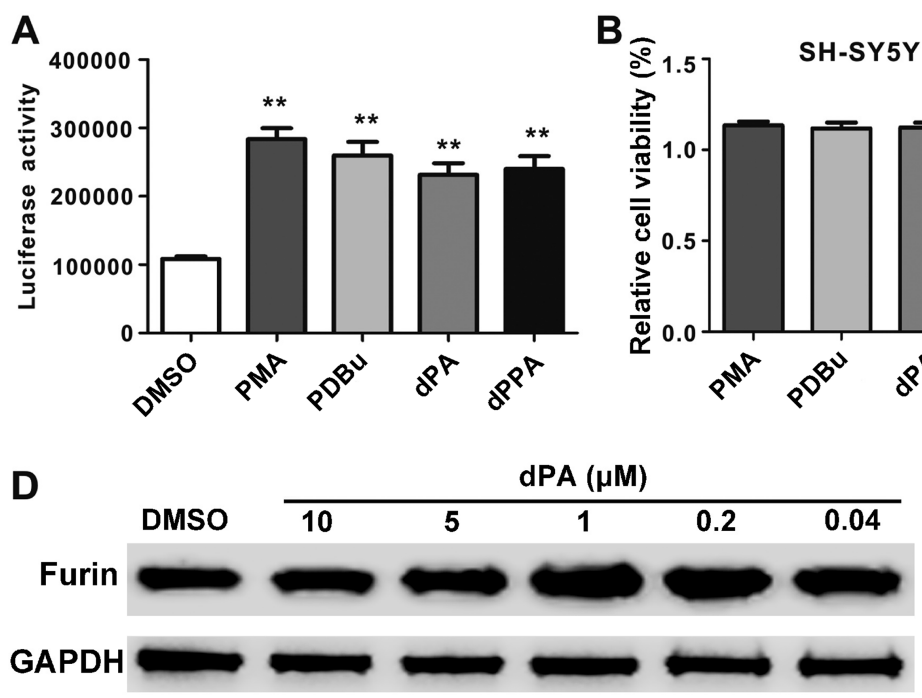
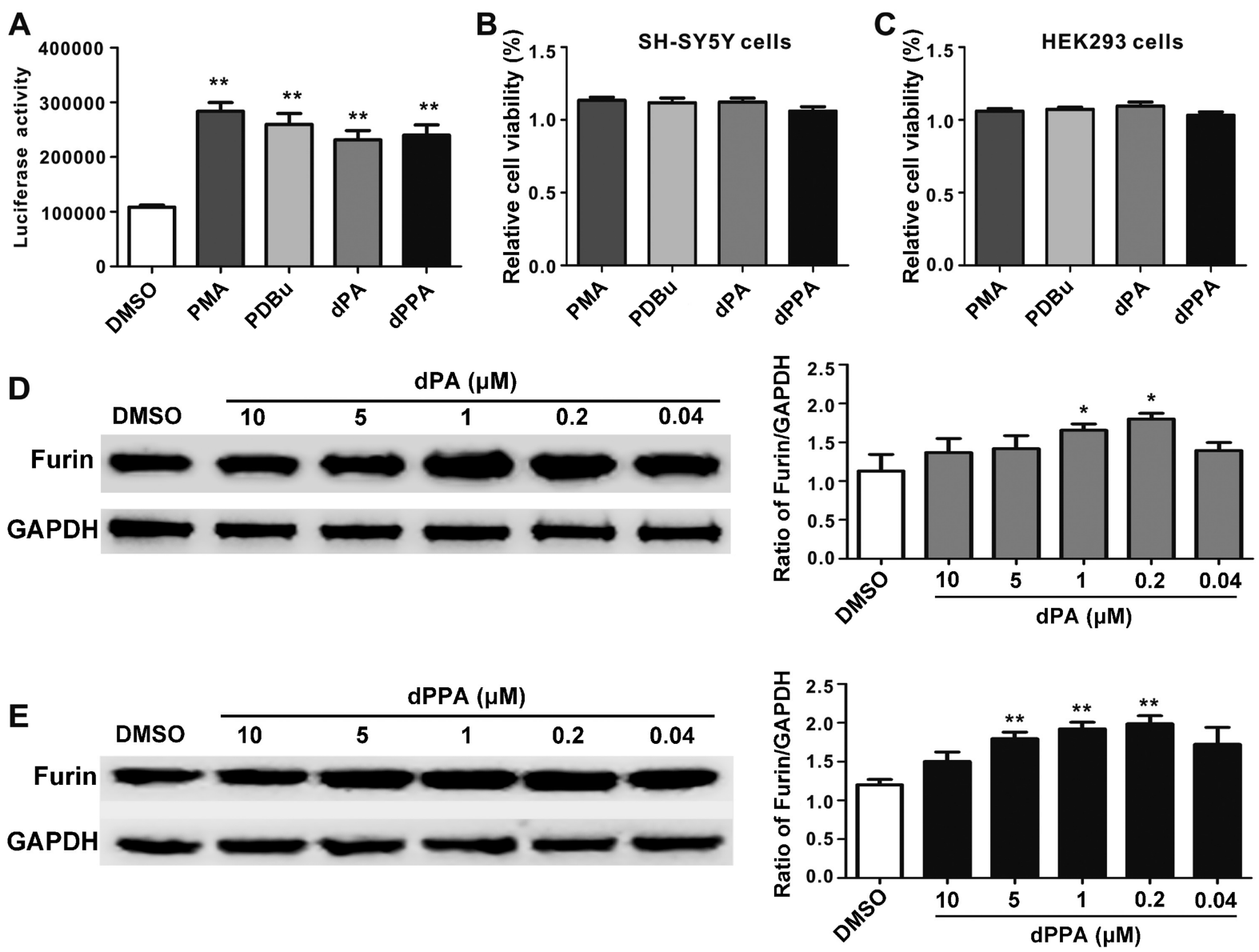

$\mathbf{F}$
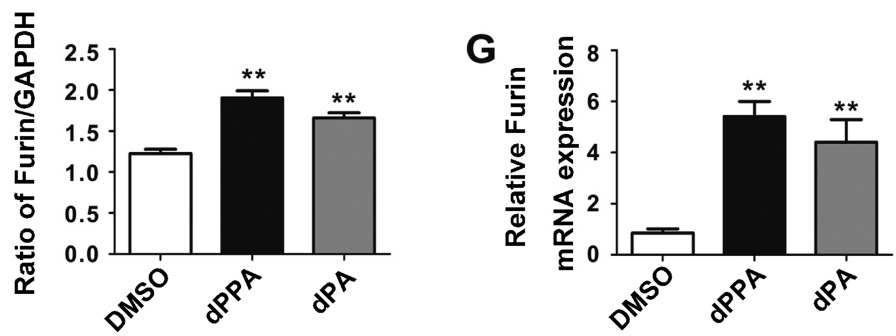

H
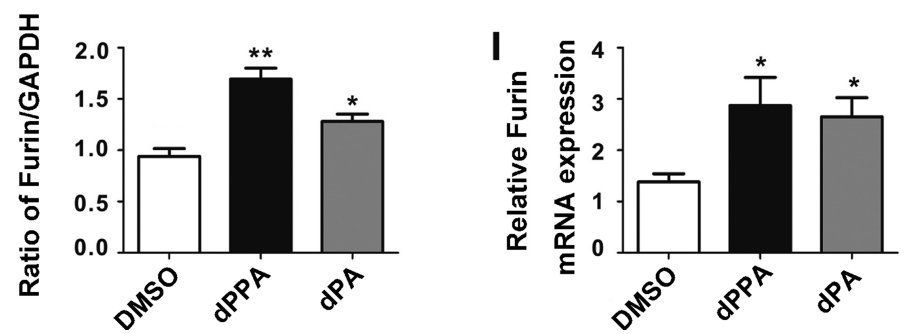

Figure 1: dPA/dPPA elevates furin expression. (A) SH-SY5Y cells stably expressing furin P1 were treated for $24 \mathrm{~h}$ with $10 \mu \mathrm{M}$ PMA, PDBu, dPA and dPPA that were found from 6988 kinds of traditional Chinese Medicine using high-throughput screening. They all promote luciferase activity of furin P1 promoter $(* * P<0.01$ ). (B and $\mathbf{C})$ SH-SY5Y and HEK293 cells were treated with $10 \mu \mathrm{M}$ PMA, PDBu, dPA and dPPA for $72 \mathrm{~h}$ and cell viability was assessed by CCK-8 assay. (D and E) SH-SY5Y cells were treated with dPA (D) and dPPA (E) at different concentrations $(0.04-10 \mu \mathrm{M})$ for $72 \mathrm{~h}$, and the expression of furin was determined by Western blot analysis ( ${ }^{*} P<0.05,{ }^{*} P<0.01$, compared to DMSO group). ( $\mathbf{F}$ and $\left.\mathbf{H}\right)$ HEK293 cells or primary neurons were treated with $0.2 \mu \mathrm{M}$ $\mathrm{dPA}$ and $\mathrm{DPPA}$ for $72 \mathrm{~h}$, and the representative Western blotting images show that the expression of furin is significantly increased compared with control $\left(* P<0.05,{ }^{*} P<0.01\right)$. (G and I) Cells were treated as described in Figure $\mathrm{F}$ and $\mathrm{H}$, the mRNA level of furin was determined by real-time PCR. $* P<0.05,{ }^{*} P<0.01$. PMA, phorbol 12-myristate 13-acetate; PDBu, phorbol (12, 13)-dibutyrate; dPA, 12-deoxyphorbol 13-acetate; dPPA, 12-deoxyphorbol 13-phenylacetate 20-acetate. 
altered as compared to control. Knockdown of GATA1 did not prevent dPPA/dPA-induced enhancement of furin in SH-SY5Y cells (Figure 4D and 4E). The transcription of GATA1 was also not affected by dPPA/dPA treatment (Figure 4F). Next, we assessed the effect of dPPA on furin expression in cells transiently overexpressing CEBP $\beta$. However, overexpression of CEBP $\beta$ did not affect the basal furin protein level and the effect of dPPA (Figure 4G). A ChIP assay further revealed that CEBP $\beta$ was able to bind to the furin promoter, and this binding was increased in the presence of dPPA (Figure 4H). These results indicated that $\mathrm{CEBP} \beta$ responsive element was involved in $\mathrm{dPPA} / \mathrm{dPA}$ regulation of furin expression.

\section{ERK and PI3K signaling were involved in DPPA regulation of furin}

Previous study has demonstrated that TGF $\beta$ stimulates P1 promoter activity, which involves $\operatorname{smad} 2$ (mothers against DPP homolog 2) and smad7 [28]. To test whether TGF $\beta$ may be involved $\mathrm{dPA} / \mathrm{dPPA}$ regulation of furin, SH-SY5Y and HEK293 cells were treated with $25 \mu \mathrm{M}$ RepSox (TGF $\beta$ pathway inhibitor) in absence or presence of dPA or dPPA for $72 \mathrm{~h}$. We found that RepSox did not cause significant alteration of furin protein compared to control. The expression of furin remained significantly increased after dPA or dPPA in the presence of RepSox (Figure 5A and 5B). dPA or dPPA also failed to increase the mRNA levels of smad2 and smad7 in SH-SY5Y cells (Figure 5C and 5D). These results indicated TGF $\beta$ signaling was not involved in $\mathrm{dPA} / \mathrm{dPPA}$ augmentation of furin.

ERK (extracellular regulated protein kinases) signaling is known to play important role in PKCregulated cellular function [29]. Interestingly, CEBP $\beta$ activity can be regulated by ERK $[30,31]$. To test whether ERK may be involved in IPPA regulation of furin, we assessed the effect of U0126 (ERK inhibitor) in SH-
A

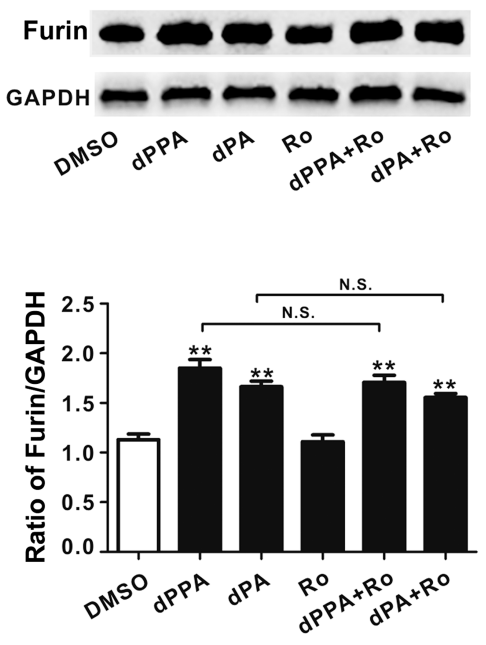

E

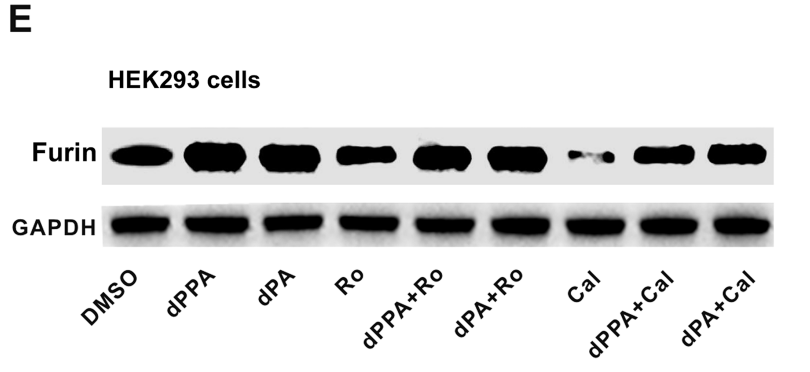

B
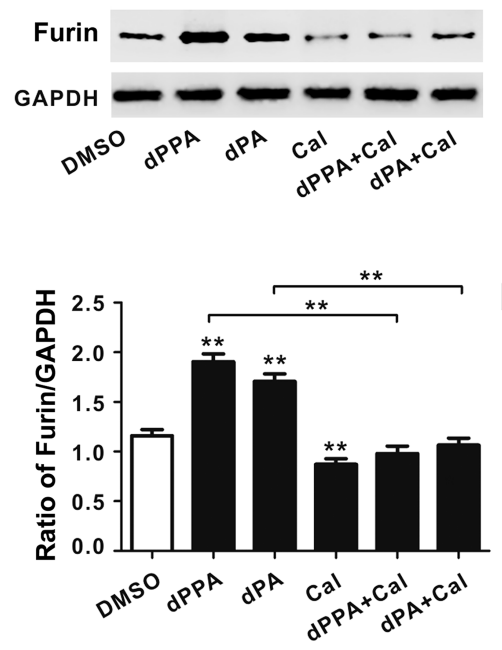

C
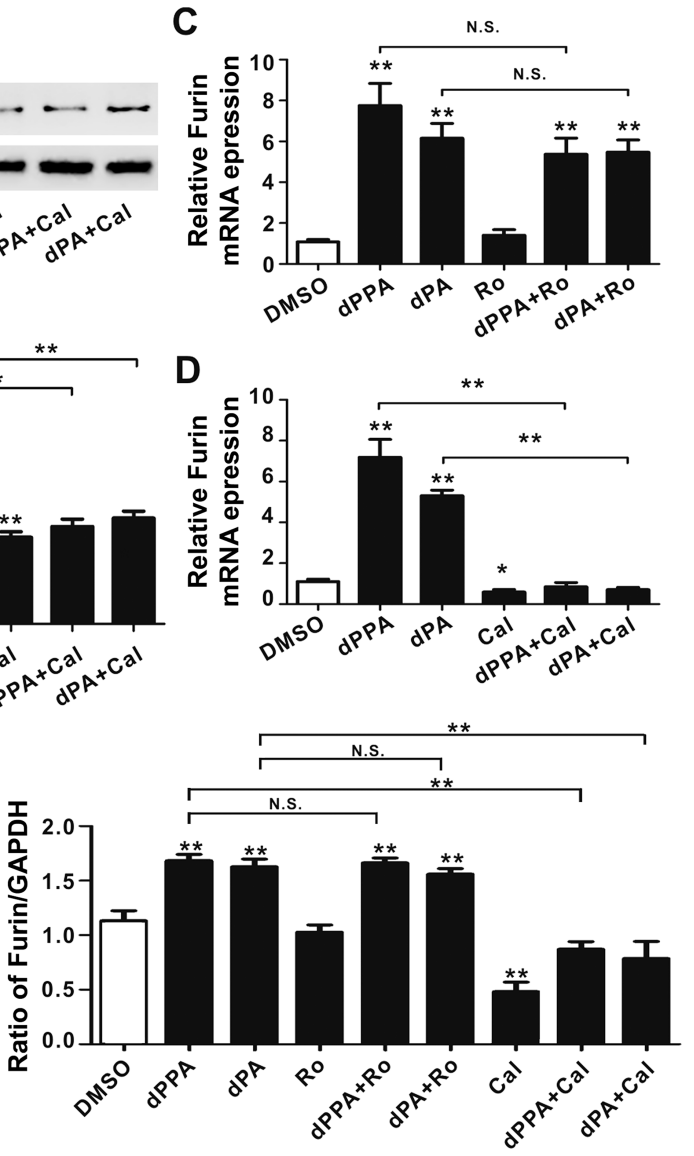

Figure 2: Effect of PKC inhibitors on dPA/dPPA induced expression of furin. (A) SH-SY5Y cells were treated with $10 \mu \mathrm{M}$ Ro318220 (Ro) in the absence or presence of $0.2 \mu \mathrm{M}$ dPPA or dPA for $72 \mathrm{~h}$, and the Western blotting results show that Ro318220 does not affect the up-regulation of furin induced by dPPA or dPA $(* * P<0.01$, n.s: non significant, compared to control). (B) SH-SY5Y cells were treated with $0.5 \mu \mathrm{M}$ calphostin $\mathrm{C}(\mathrm{Cal})$ in the absence or presence of $0.2 \mu \mathrm{M}$ dPPA or dPA for $72 \mathrm{~h}$, and the Western blotting results show that the induction of furin by dPPA or $\mathrm{APA}$ is diminished in the presence of calphostin $\mathrm{C}$ ( $* * P<0.01$, compared to control). (C and D) SH-SY5Y cells were treated as described in Figure 2A and 2B, the mRNA level of furin was determined by real-time PCR $\left({ }^{*} P<0.05,{ }^{*} * P<0.01\right.$, n.s: non significant, compared to control). (E) HEK293 cells were treated with $10 \mu \mathrm{M}$ Ro318220 (Ro) or $0.5 \mu \mathrm{M}$ calphostin $\mathrm{C}(\mathrm{Cal})$ in the absence or presence of $0.2 \mu \mathrm{M}$ dPPA or dPA for $72 \mathrm{~h}$, and the Western blotting results show that calphostin $\mathrm{C}$ rather than Ro318220 inhibits the up-regulation of furin induced by dPPA or dPA. ${ }^{*} P<0.01$, n.s: nonsignificant, compared to control. 
SY5Y cells, LY294002 (PI3K inhibitor) was used as a control. As expected, U0126 or LY294002 diminished rather than completely blocked the effect of dPPA on furin protein expression (Figure 5E). Meanwhile, in cells overexpressing CEBP $\beta$, U0126 or LY294002 had no effect on furin expression (Figure $5 \mathrm{~F}$ ). The combined treatment of U0126 with LY294002 completely inhibited dPPA induced furin expression (Figure 5G). These results suggested that ERK and PI3K signaling pathways were involved in $\mathrm{APPA}$ regulation of furin.

\section{DISCUSSION}

Phorbol ester regulation of neuronal gene expression has been documented. In GT1 cell line, phorbol esters enhance gonadotropin-releasing hormone and $c$-fos genes $[32,33]$. In rat hypothalamic culture, 12-O-tetradecanoylphorbol-13-acetate increases the protein level of thyrotropin releasing hormone and CREB [34]. In neuroblastoma cell lines, phorbol ester regulates vasoactive intestinal peptide gene expression [35]. Here we provide evidence that phorbol esters significantly increase furin gene expression in neuronal cells. We also show that this effect is not neuron-specific, as similar effect and mechanisms have been shown in HEK293 cells as well.

Phorbol esters enter freely into the cells and are preferentially localized to membraneous structures including endoplasmic reticulum, Golgi, mitochondrial and nuclear membranes [36, 37]. Protein kinase C (PKC) isoforms have been identified as phorbol ester receptors $[22,38]$, which play important roles in various biological phenomena $[39,40]$. It seems that the $\mathrm{C} 1$ domain mediates phorbol ester binding to PKC [41, 42]. Phorbol esters insert into the hydrophilic cleft of $\mathrm{C} 1$ domains, favoring PKC association with lipid membranes [43, 44]. The conformational flexibility of $\mathrm{C} 1$ domains determines differential activation mechanisms of PKCs [45]. In our studies, dPA/dPPA-induced furin expression is blocked by calphostin $\mathrm{C}$ that competitively binds to $\mathrm{C} 1$ domain of PKC, but not by Ro318220 that acts on the catalytic domain of PKC by competing with ATP binding,

A

(pGL4.17-)

LUC (-8673/-7405) Furin-P1-A

-LUC (-7925/-7426) Furin-P1-B

LUC (-8734/-7426) Furin-P1-C

[LUC (-8673/-7925) Furin-P1-E

LUC (-7925/-7405) Furin-P1-G

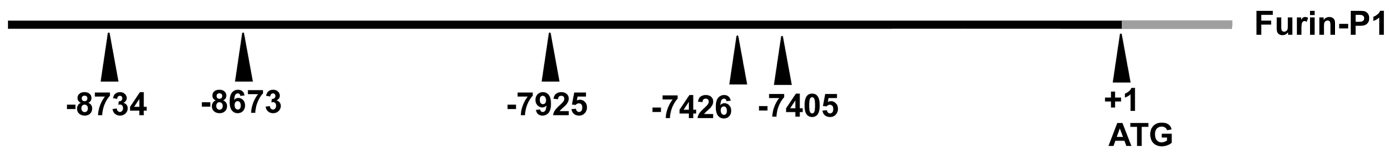

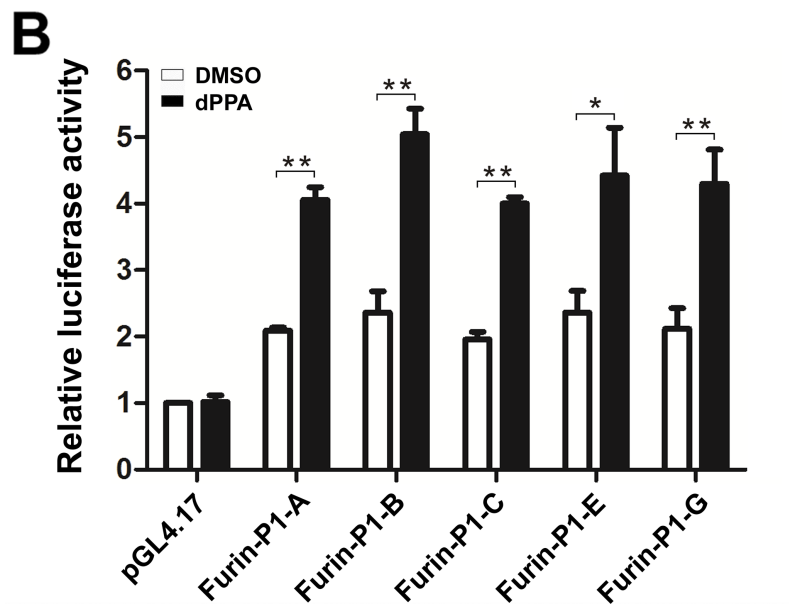

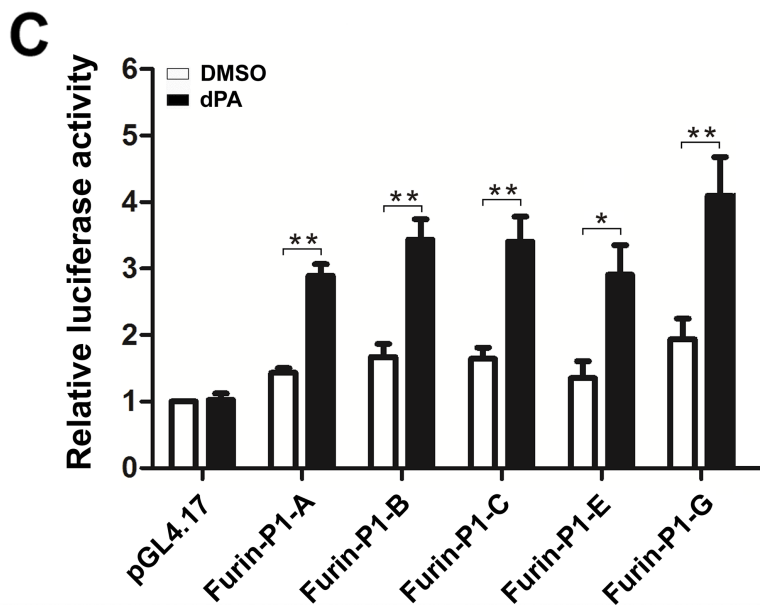

Figure 3: Identification of the core fragments in furin P1 promoter. (A) Schematic representation of the truncated furin $\mathrm{P} 1$ promoter fragments. Numbers indicate the relative positions with respect to the ATG start codon $(+1)$. The black line represents the $5^{\prime}$ genomic region of the furin gene, the gray line represents the furin cDNA sequence, and the rectangle represents the firefly luciferase coding region (LUC). (B and C) SH-SY5Y cells were transiently transfected with Furin-P1-A, Furin-P1-B, Furin-P1-C, Furin-P1-E, Furin-P1-G and pGL4.17 (negative control) for $24 \mathrm{~h}$ and then treated with $0.2 \mu \mathrm{M}$ dPPA (B) or dPA (C) for another $24 \mathrm{~h}$. The luciferase activity was measured and the relative fold activation of each truncated promoter fragments normalized to pGL4.17 internal standard (the luciferase activity of pGL4.17 treated with DMSO was set as 1) was presented. The results represent the average and SEM of three independent experiments. $* P<0.05, * * P<0.01$, compared to control. 
A

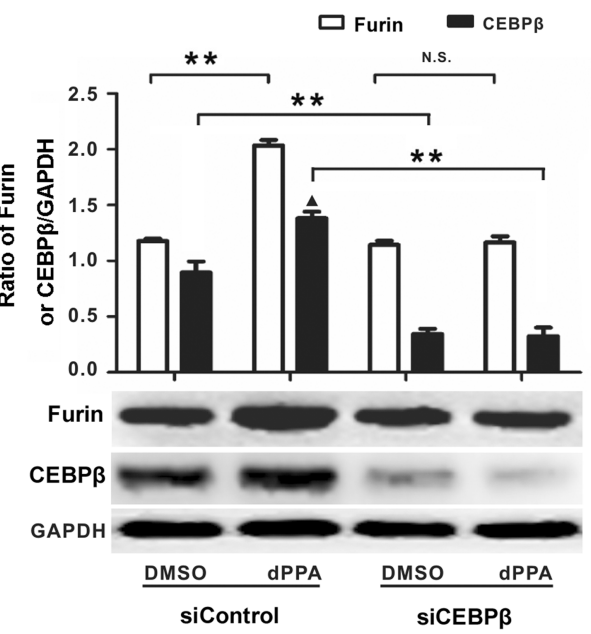

D

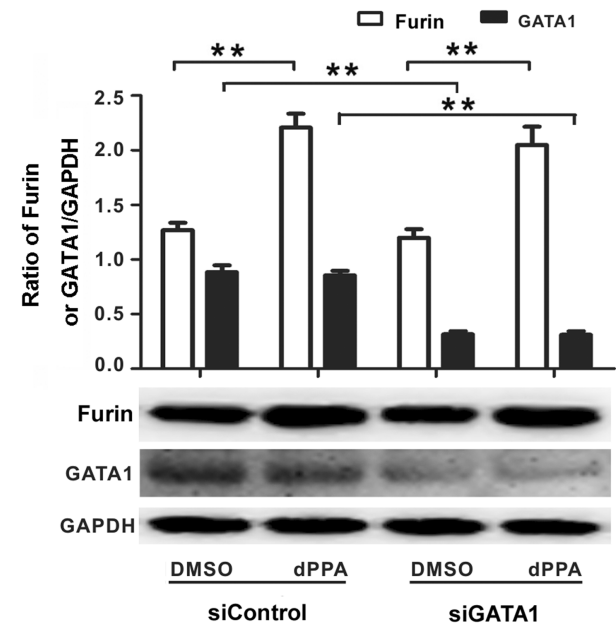

B

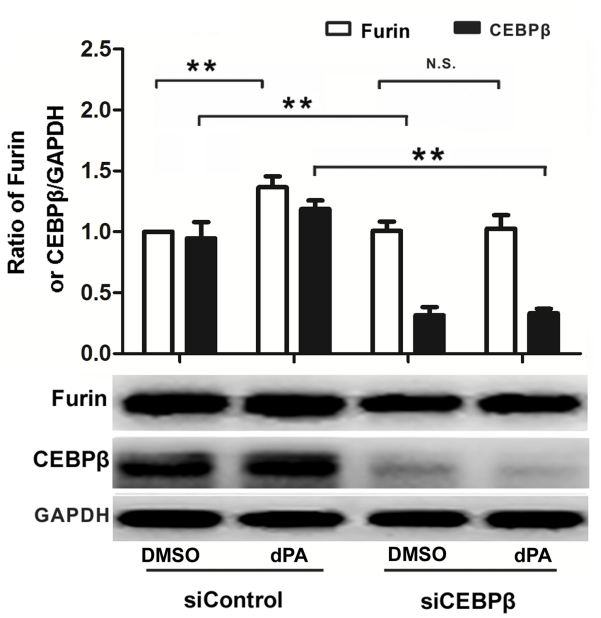

$\mathbf{E}$

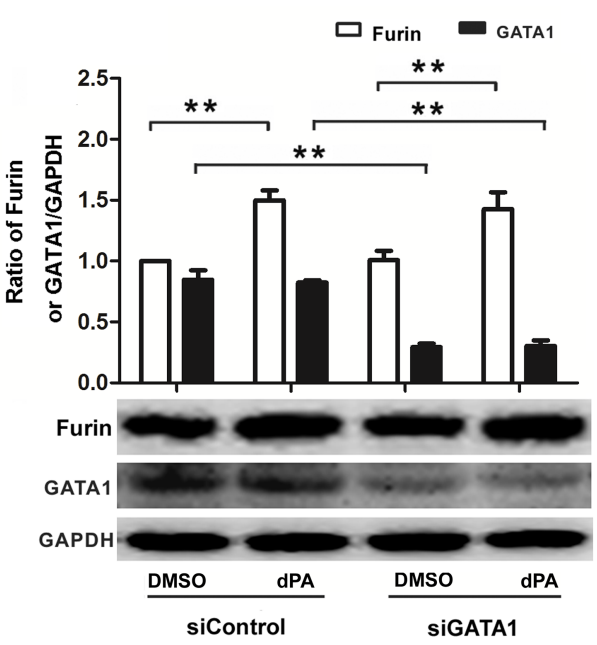

C

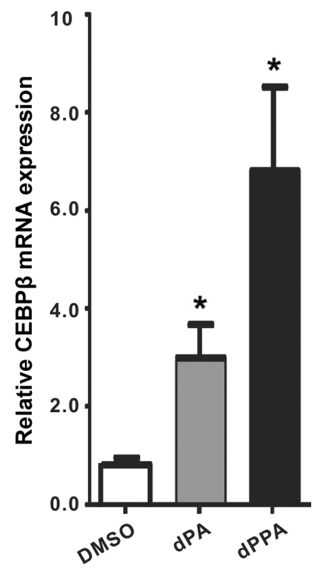

$\mathbf{F}$

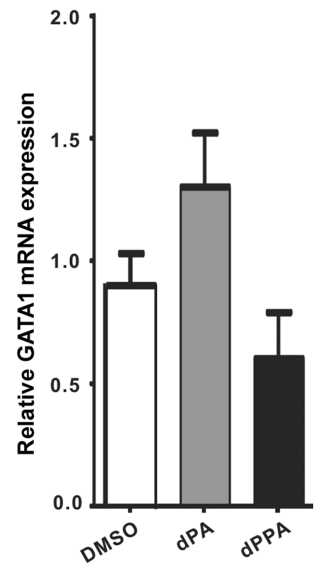

G

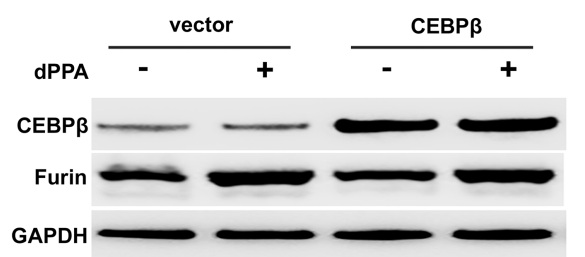

H

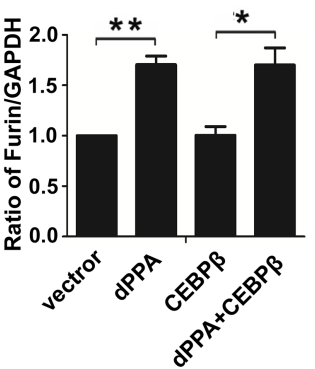

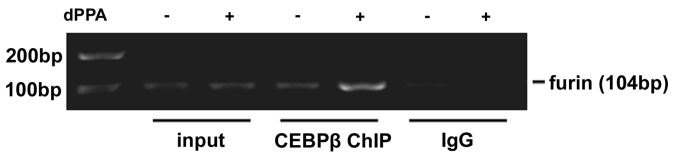

Figure 4: dPPA/dPA regulation of furin requires transcription factor CEBPß. (A and B) SH-SY5Y cells were transfected with $C E B P \beta$ siRNA (siCEBP $\beta$ ) or control siRNA (siControl) for $24 \mathrm{~h}$ and then treated with $0.2 \mu \mathrm{M}$ dPPA (A) or dPA (B) for $72 \mathrm{~h}$. Western blotting results show that the inhibition of $C E B P \beta$ blocks the effect of dPPA/dPA on furin expression. (C) SH-SY5Y cells were treated with $0.2 \mu \mathrm{M}$ dPPA or dPA for $72 \mathrm{~h}$, and mRNA levels of $C E B P \beta$ were determined by real-time PCR. (D and E) SH-SY5Y cells were transfected with GATA1 siRNA (siGATA1) or control siRNA (siControl) for $24 \mathrm{~h}$ and then treated with $0.2 \mu \mathrm{M}$ dPPA (D) or dPA(E) for $72 \mathrm{~h}$. Western blotting results show that dPPA/dPA still increases the expression of furin after GATA1 is knockdown. (F) SH-SY5Y cells were treated with $0.2 \mu \mathrm{M}$ dPPA or dPA for $72 \mathrm{~h}$, and mRNA levels of GATA1 were determined by real-time PCR. (G) SH-SY5Y cells were transfected with pcDNA3-CEBP $\beta$ or pcDNA3 (vector) for $24 \mathrm{~h}$ and then treated with $0.2 \mu \mathrm{M} \mathrm{dPPA}$ for $72 \mathrm{~h}$, and the Western blotting results show that CEBP $\beta$ overexpression did not affect the basal furin protein level and the effect of dPPA. (H) SH-SY5Y cells were treated with $0.2 \mu \mathrm{M}$ dPPA for $72 \mathrm{~h}$, and then ChIP analysis was performed using ChIP assay kits with a CEBP $\beta$ antibody. The input or immunoprecipitated DNA was subjected to PCR amplification using primers specific to the furin promoter. ${ }^{*} P<0.05,{ }^{* *} P<0.01$, n.s: nonsignificant, compared to control. 
suggesting that the $\mathrm{C} 1$ domain rather than the catalytic domain of PKC mediates the up-regulation of furin gene.

Furin gene is controlled by three distinct promoters known as P1, P1A and P1B [26]. While P1A and P1B promoters are considered as housekeeper genes, P1 promoter is under the control of variety of transcriptional factors, including CEBP $\beta$, GATA1, HIF-1, Smads, CREB and CDX2 [26-28, 46-48]. In SH-SY5Y cells in our study, nucleotides -7925 to -7405 in $\mathrm{P} 1$ promoter effectively mediate $\mathrm{dPPA}$ or $\mathrm{dPA}$ induced luciferase activity. We further identify that CEBP $\beta$ is involved in dPPA/dPA induced enhancement of furin, as revealed by siRNA experiments. However, another transcription factor GATA1 was not involved in $\mathrm{dPPA} / \mathrm{dPA}$ regulation of furin gene in SH-SY5Y cells, which is in contrast to the previous report that in megakaryocytes, PMA promotes furin expression through GATA1 in P1 promoter [27]. As described above, PMA and IPPA may differ in functions.
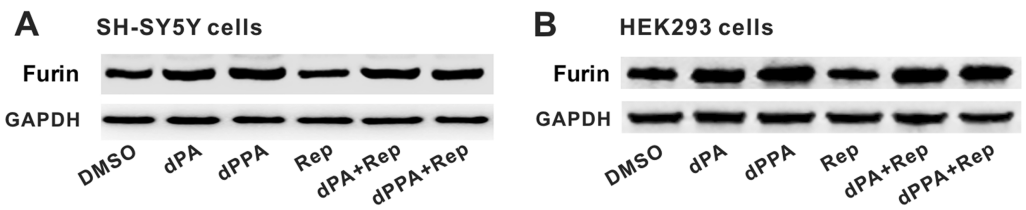

C
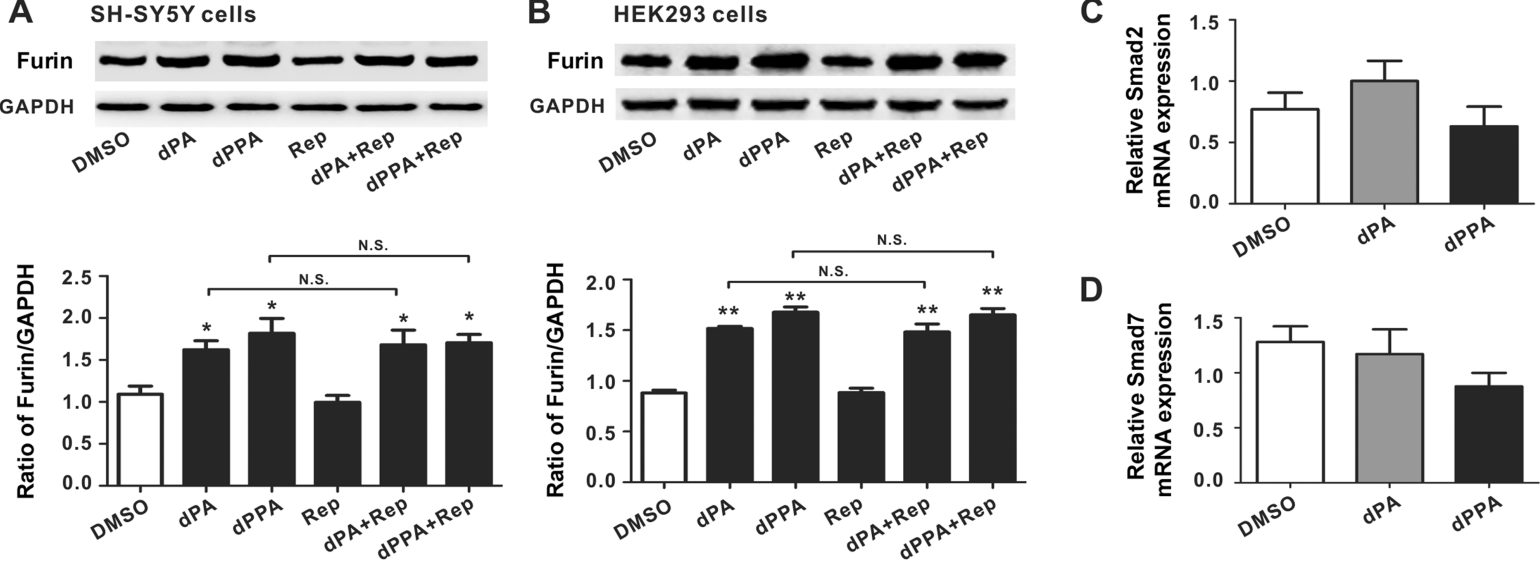

D

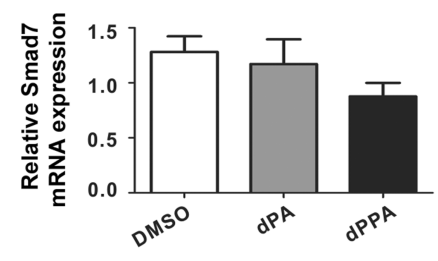

E

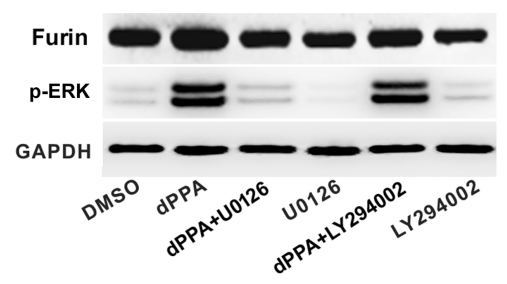

F

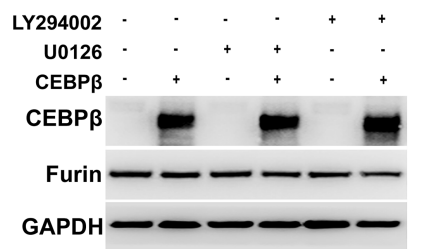

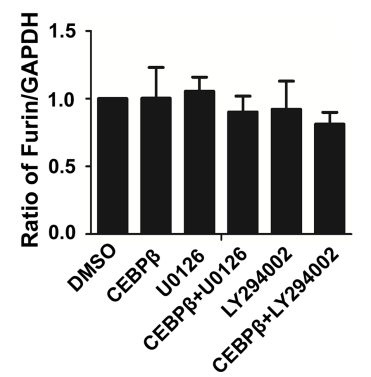
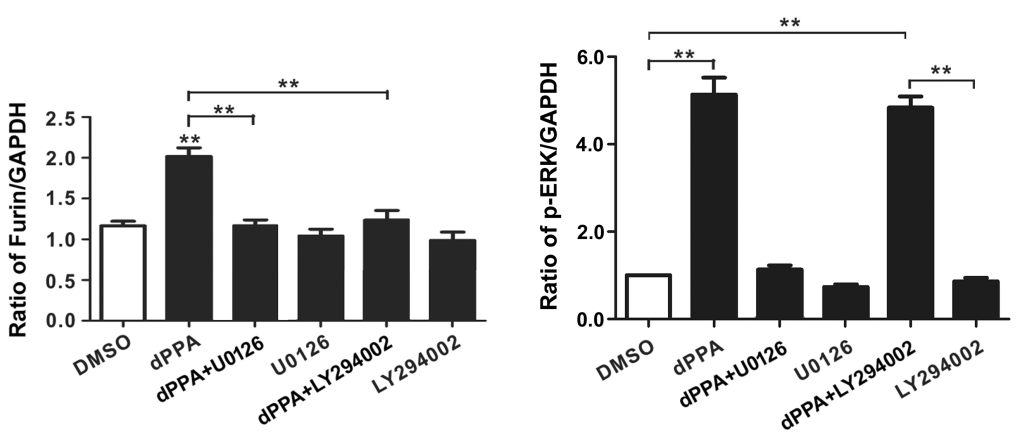

$\mathbf{G}$ 
The former is carcinogenic while the latter is antineoplastic [19-21]. Another possibility is that P1 promoter may be activated in a tissue- and cell differentiation-dependent manner [26]. It is also unlikely that TGF $\beta$ signaling is involved, as TGF $\beta$ receptor antagonist does not prevent dPPA effect on furin. In HepG2 cells, the key fragments for TGF $\beta$ and Smads to take effect are at position -8734 and -7925 [49], which are not included in the region $(-7925$ to -7405$)$ identified in our study.

$\mathrm{C} 1$ domain has been considered as phorbol ester receptor in PKC and other proteins [50]. Interestingly, many of these proteins including PKD (protein kinase D), c-Raf (Raf-1 proto-oncogene, serine/threonine kinase) and Ras-GRP (Ras guanyl releasing protein) share with PKC the common signaling pathway, resulting in activation of Raf-ERK [29, 50, 51]. It is reported that ERK could promote the phosphorylation of CEBP $\beta[30,31]$. Thus CEBP $\beta$ may link phorbol ester to furin expression. However, why PI3K inhibitor also diminishes dPPA effect on furin is not well-understood. Study has demonstrated that promotion of neurite growth by phorbol esters can be blocked by PI3K inhibitor [52]. Genes associated with PI3K signaling are significantly affected by PMA in human monocytic cell line [53]. A recent study shows that PI3K is involved in EGF-induced prolactin receptor expression, which is dependent on Sp1/CEBP $\beta$ complex [54]. Thus, it may be reasonable to speculate that phorbol esters act on $\mathrm{C} 1$ domain proteins and plasma membrane receptors leading to downstream activation of ERK and PI3K. In our study, ERK and PI3K may work synergistically, as the basal level of furin protein was reduced only when both inhibitors are administered (Figure 5G).

It is interesting that both knockdown and overexpression of CEBP $\beta$ fail to affect basal furin protein (Figure 4). While CEBP $\beta$ knockdown prevents dPPA/ dPA enhancement of furin (Figure 4A and 4B), CEBP $\beta$ overexpression is without effect (Figure 4G). We speculate that $\mathrm{CEBP} \beta$ is constitutively active, and its functional role may be tightly regulated by phosphorylation, which involves other CEBP members. Study has shown that $\mathrm{CEBP} \beta$ and $\mathrm{CEBP} \delta$ are key transcriptions factors that mediate cytokine production in macrophage. In contrast, macrophages deficient of CEBP $\beta$ or $\mathrm{CEBP} \delta$ fail to show significant decrease of cytokines [55]. The synergistic effect of CEBP $\beta$ and CEBP $\delta$ has been shown for mice lacking these two factors that exhibit defective adipocyte differentiation [56]. Although it is not currently clear which CEBP subtypes may play a role, they all contain phosphorylation sites [30]. Some of them are known to be regulated by $\mathrm{PKC}$ and downstream signaling resulting in altered DNA binding and gene expression $[57,58]$. Thus, it is not surprising that overexpression of CEBP $\beta$ alone fails to induce furin expression (Figure 4G), which also fails to bypass the ERK or PI3K inhibition on furin induction by dPPA. A working model is that the constitutively active CEBP $\beta$ may interact with other CEBP members, and their bindings to P1 promoter are critically dependent on ERK and PI3K. In line with this, ERK phosphorylation of another transcription factor USF1 (upstream transcription factor 1) is suggested to be prerequisite to USF1-mediated gene expression $[59,60]$.

We propose the potential mechanisms that dPPA/ dPA increases furin expression. Upon dPPA/dPA binding to $\mathrm{C} 1$ domain containing proteins and perhaps plasma membrane receptors, downstream ERK and PI3K are activated, which may work synergistically to promote CEBP $\beta$ association with $\mathrm{P} 1$ promoter and perhaps with other CEBP members, leading to the increased expression of furin protein (Figure 6). However, how CEBP $\beta$ may be associated with other CEBP members, and which subtypes may be involved, remain to be investigated in the future. Nonetheless, dPPA/dPA regulation of furin in neuronal cells may shed new light on the understanding of neurological diseases, especially Alzheimer's disease.

\section{MATERIALS AND METHODS}

\section{Chemicals}

The PMA, PDBu, dPA, dPPA, LY294002 (PI3K inhibitor) and U0126 (ERK inhibitor) were obtained from Sigma (Saint Louis, USA). Calphostin C was ordered from Cayman (Michigan, USA). RepSox (TGF $\beta$ pathway inhibitor) was from MedChemExpress (MCE, New Jersey, USA). Ro318220 were from Santa Cruz (Santa Cruz Biotechnology, California, USA). All chemicals were dissolved in DMSO (sigma) to generate a $50 \mathrm{mM}$ stock solution, with final dilutions of at least 1:2000.

\section{Plasmids construction}

Human genomic DNA was extracted from cultured cells and used as a template for amplification of a 1268bp (-8673/-7405) fragment, named Furin-P1-A, consisting of the human furin $\mathrm{P} 1$ promoter and its upstream sequence [18]. The Furin-P1-A was further divided into four fragments which contain DNA fragments from -7925 to -7426bp (Furin-P1-B), -8734 to -7426bp (Furin-P1-C), -8673 to $-7925 b p$ (Furin-P1-E), and -7925 to $-7405 b p$ (Furin-P1-G), respectively. The fragments of furin P1 were subsequently subcloned into the luciferase reporter vector pGL4.17 (Promega, Madison, USA). All constructs were amplified by PCR with their specific primers listed in Table 1 and confirmed by DNA sequencing.

\section{Cell culture, stable cell line generation and pharmacological treatments}

Human neuroblastoma cells (SH-SY5Y) and human embryonic kidney 293 cells (HEK293) were obtained Shanghai Institute of Biological Sciences (Chinese Academy of Sciences, China). SH-SY5Y cells were 
Table 1: Primers of different furin $\mathbf{P 1}$ promoters for plasmids construction

\begin{tabular}{lll}
\hline Name & Sequence & $\begin{array}{l}\text { Size (bp) } \\
\text { (Start-Stop) }\end{array}$ \\
\hline Furin-P1-A & 5'-GCCGGCTAGCACCACCATCCTGTGACGTTCCC-3' & 1268 \\
& 5'-CCCAAGCTTCTGCTGCTTCCCCGCCACTC-3' & $(-8673 /-7405)$ \\
Furin-P1-B & 5'-GCCGGCTAGCCTCCATGCAACCCTACTAGAGAGGTG-3' & 499 \\
& 5'-CCCAAGCTTCTGCAGCTGCAACAGTCAGGC-3' & $(-7925 /-7426)$ \\
Furin-P1-C & 5'-GCCGGCTAGCCTAGCTGTCTCAGAGCTTAGTTCCCAG-3' & 1308 \\
& 5'-CCCAAGCTTCTGCAGCTGCAACAGTCAGGC-3' & $(-8734 /-7426)$ \\
Furin-P1-E & 5'-GCCGGCTAGCACCACCATCCTGTGACGTTCCC-3' & 748 \\
& 5'-CCCAAGCTTGGAGGTACCTGGGACACACCAGG-3' & $(-8673 /-7925)$ \\
Furin-P1-G & 5'-GCCGGCTAGCCTCCATGCAACCCTACTAGAGAGGTG-3' & 520 \\
& 5'-CCCAAGCTTCTGCTGCTTCCCCGCCACTC-3' & $(-7925 /-7405)$ \\
\hline
\end{tabular}

maintained in Dulbecco's modified eagle's medium/ nutrient mixture F12 (DMEM/F12, Gibco, Grand Island, USA) with $10 \%$ FBS (Gibco) plus $100 \mathrm{U} / \mathrm{ml}$ penicillin and $100 \mu \mathrm{g} / \mathrm{ml}$ streptomycin. HEK293 cells were grown in DMEM (Gibco), supplemented with 10\% FBS, $100 \mathrm{U} /$ $\mathrm{ml}$ penicillin and $100 \mu \mathrm{g} / \mathrm{ml}$ streptomycin.
SH-SY5Y cells stably expressing furin $\mathrm{P} 1$ promoters were generated by using G418 $(0.5 \mathrm{mg} / \mathrm{ml})$ selection to screen for SH-SY5Y clones transiently transfected with pGL4.17-Furin-P1 using lipofectamine 2000 (Invitrogen, Carlsbad, USA). The medium was replaced by complete medium after $6 \mathrm{~h}$, and cells were incubated for $24 \mathrm{~h}$. The

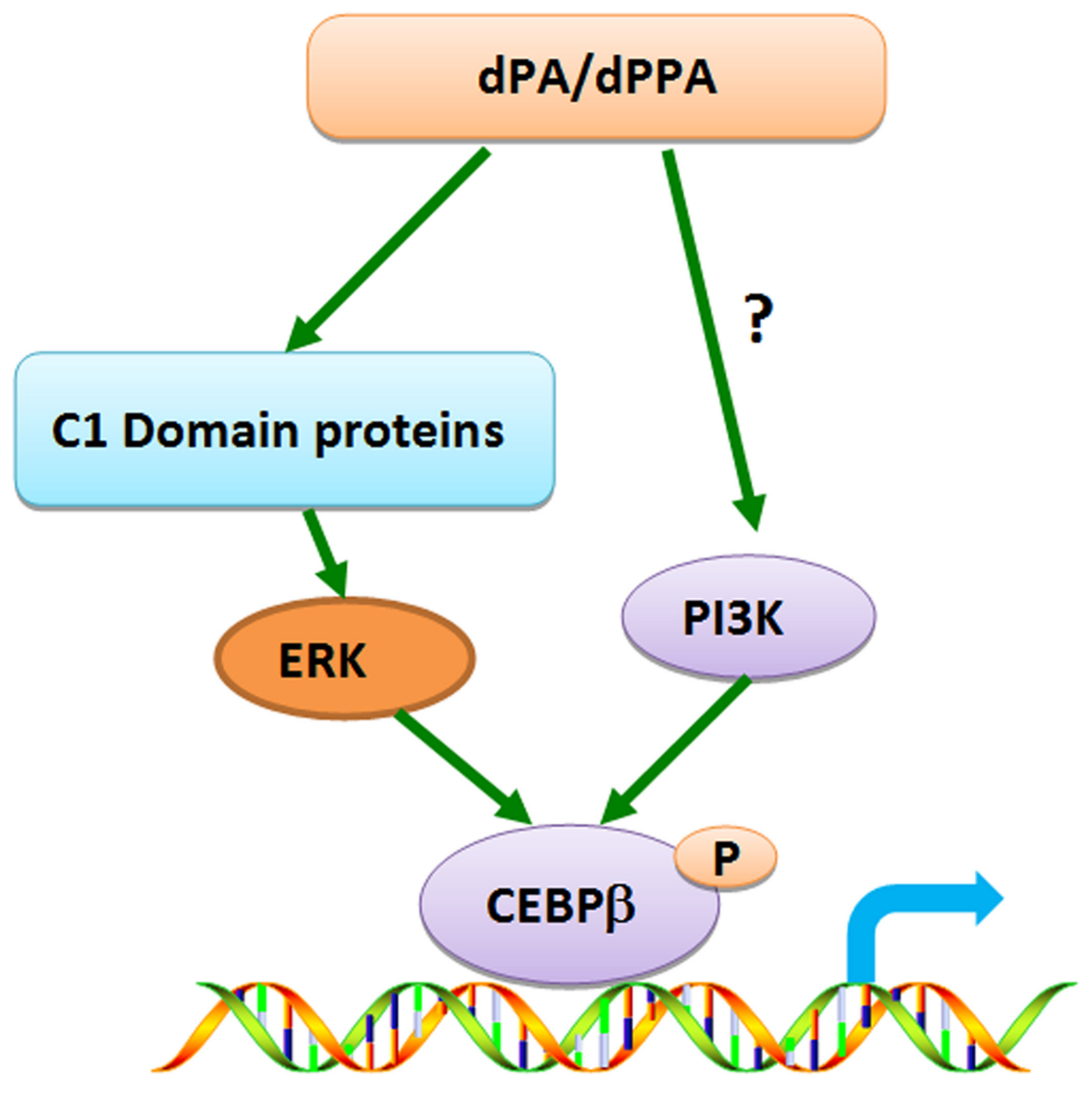

Furin Promoter

Figure 6: Schematic diagram depicting the possible mechanisms through which dPPA/dPA regulates furin transcription. dPPA/dPA enters freely into the cells and preferentially binds $\mathrm{C} 1$ domain-containing proteins and perhaps plasma membrane receptors. This leads to the downstream activation of ERK and PI3K, which may synergistically promote CEBP $\beta$ association with P1 promoter and with other CEBP members (not shown), resulting in the enhanced expression of furin. 
cell monolayers were then grown in DMEM/F12 with $10 \% \mathrm{FBS}$ and $0.2 \mathrm{mg} / \mathrm{ml} \mathrm{G} 418$ for later screening of cells. Primary cortical neurons were prepared from Sprague-Dawley rat embryos at day 17-18 and treated with $0.25 \%$ trypsin-EDTA for $15 \mathrm{~min}$. The digested tissues were dissociated by trituration and plated on dishes overnight, and the cultures were maintained in DMEM for $24 \mathrm{~h}$. Subsequently, replaced the medium with fresh Neurobasal medium (Invitrogen) supplemented with 2\% B27 (Invitrogen), $100 \mathrm{U} / \mathrm{ml}$ penicillin, $100 \mu \mathrm{g} / \mathrm{ml}$ streptomycin and $0.5 \mathrm{mM}$ glutamine. Every 2-3 days, half of the medium was removed and replenished with the fresh Neurobasal medium. Neurons were used for experiments at 7-11 days in vitro. All procedures were carried out in accordance with the Chongqing Medical University guidelines for the care and use of laboratory animals. All cells were maintained at $37^{\circ} \mathrm{C}$ under $5 \% \mathrm{CO}_{2}$ atmosphere.

Cells were transfected with luciferase reporter plasmids or pcDNA3-CEBP $\beta$ (Origene, Rockville, USA) and then were treated with PMA, PDBu, dPA or APPA with indicated concentrations for $72 \mathrm{~h}$. To investigate the signaling pathways involved in the dPPA/dPA-mediated effect, cells were treated with the $0.5 \mu \mathrm{M}$ calphostin $\mathrm{C}$ (PKC inhibitor), $10 \mu \mathrm{M}$ Ro318220 (PKC inhibitor), 25 $\mu \mathrm{M}$ RepSox (TGF $\beta$ pathway inhibitor), $10 \mu \mathrm{M}$ LY294002 (PI3K inhibitor) or/and $20 \mu \mathrm{M} \mathrm{U} 0126$ (ERK inhibitor) for $72 \mathrm{~h}$ in the absence or presence of dPPA/dPA.

\section{Luciferase activity assay}

For high-throughput small-molecule screening, SHSY5Y cells stably expressing furin P1 promoters were seeded onto 384-well plates for $24 \mathrm{~h}$ and were treated with 6990 small molecules at a concentration of $10 \mu \mathrm{M}$ for $24 \mathrm{~h}$. For identifying the core fragments in furin P1 promoter, SH-SY5Y cells were seeded into 96-well plates $\left(0.8-1.0 \times 10^{4}\right.$ cells per well) $24 \mathrm{~h}$ before transfection. Then, cells were transiently transfected with $0.2 \mu \mathrm{g}$ luciferase reporter plasmids (pGL4.17-Furin-P1-A E) and pGL4.17 (a negative control) using Lipofectamine 2000 according to the manufacturer's instructions. 24 hours after transfection, PMA, PDBu, dPA or $\mathrm{dPPA}(0.2 \mu \mathrm{M})$ was added to cells, and DMSO was used as a negative control. The luciferase activities were measured using a luciferase assay kit (Promega, Madison, Wisconsin, USA) according to the manufacturer's instructions and the relative fold activation of each construct normalized to pGL4.17 internal standard (the luciferase activity of pGL4.17 treated with DMSO was set as 1.0) was presented. The data presented as mean luciferase activity $\pm \mathrm{SEM}$.

\section{RNA interference}

The siRNA oligonucleotides for human $C E B P \beta$ and GATA1 were synthesized by Shanghai
GenePharma Co., Ltd (Shanghai, China), and the non-targeting control siRNA (siControl) was used as the negative control. The $C E B P \beta$ siRNA sequence is 5'-GCUGACAGUUACACGUGGGtt-3', GATA1 siRNA sequence is 5'-GGUACUCAGUGCACCAACUtt-3' and siControl sequence is $5^{\prime}$-UUCUCCGAAC GUGUCACGUtt-3'. SH-SY5Y cells were transfected with $50 \mathrm{nM}$ siRNAs for $6 \mathrm{~h}$ using Lipofectamine 2000 according to the manufacturer's protocol. $24 \mathrm{~h}$ after transfection, the cells were treated with $0.2 \mu \mathrm{M}$ dPPA for another $72 \mathrm{~h}$. Inhibition of target genes was confirmed by Western blotting.

\section{RNA isolation and quantitative real-time PCR}

Total RNA from cells with or without treated with chemicals was extracted with TRIzol reagent (TaKaRa, Dalian, China). cDNA synthesis was performed using a PrimeScript RT reagent kit (Vazyme Biotech, Nanjing, China). Quantitative real-time PCR (qPCR) reactions were performed on a Bio-Rad $\mathrm{IQ}^{\mathrm{TM}} 5$ detection system (Bio-Rad, Hercules, CA, USA) with a SYBR green master mix (TaKaRa) as recommended by the manufacturer. The qPCR primers used in this study are listed in Table 2. Each sample was carried out in triplicate, and the average cycle threshold value $(\mathrm{Ct})$ for housekeeping gene $G A P D H$ was used to normalize the raw cycle threshold data. The relative mRNA expression levels of the individual samples were calculated by the $2^{-\Delta \Delta C T}$ method.

\section{Protein extraction and Western blot}

All cells with or without treated with chemicals were lysed in RIPA buffer (50 mM Tris, $1 \mathrm{mM}$ EDTA, $150 \mathrm{mM} \mathrm{NaCl}, 1 \%$ Triton X-100, 0.1\% SDS, 0.5\% sodium deoxylcholate) including protease inhibitors (Roche, Indianapolis, USA). Protein concentrations were measured using a BCA Protein Assay Kit (Dingguo, Beijing, China). Equal amounts of protein extracts were separated on a $12 \%$ SDS-PAGE gel and then transferred onto PVDF membrane (Millipore, Billerica, MA, USA). Membranes were blocked by $5 \%$ nonfat dry milk in TBST (25 mM Tris, $\mathrm{pH} 7.4,1.5 \mathrm{M} \mathrm{NaCl}$, and $0.05 \%$ Tween-20) for $1 \mathrm{~h}$ at RT and probed with primary antibodies against furin (Abcam, Cambridge, UK), CEBP $\beta$ (Cell Signaling Technology, Danvers, MA, USA), GATA1 (Cell Signaling Technology), and GAPDH (Proteintech, Wuhan, Chian) overnight at $4^{\circ} \mathrm{C}$. The blots were washed and incubated for $1 \mathrm{~h}$ with HRP-conjugated anti-rabbit or anti-mouse secondary antibodies (Proteintech). The bands were visualized using an ECL reagent (Advansta Inc., Menlo Park, CA, USA) and a Fusion FX5 image analysis system (Vilber Lourmat, Marne-la-Vallée, France). Relative protein expression levels were calculated using the Quantity One software (Bio-Rad) with normalization to the GAPDH signal. 
Table 2: qPCR primers used in this study

\begin{tabular}{clc}
\hline Gene & \multicolumn{1}{c}{ Sequence } & Tm \\
\hline \multirow{2}{*}{ Furin } & 5'-TGCCACGCCTCATGTGCC-3' & 64.00 \\
& 5'-GCTCTGGCTTTGCCGGGA-3' & 63.30 \\
Smad2 & 5'-GAGATATGGCTGGCACCCTG-3' & 60.25 \\
& 5'-TGCCTTCGGTATTCTGCTCC-3' & 59.82 \\
Smad7 & 5'-GTCAAGAGGCTGTGTTGCTG-3' & 59.41 \\
& 5'-ATCTGGACAGTCAGTTGGTTTG-3' & 58.52 \\
CEBP $\alpha$ & 5'-GGAGCTGACCAGTGACAATGACC-3' & 59.59 \\
& 5'-CTGGCAGCTGGCGGAAGAT-3' & 58.02 \\
CEBP $\beta$ & 5'-GCCACGGCCACGGACACCTT-3' & 63.44 \\
& 5'-TCGGCCGGCTTCTTGCAGTTCTT-3' & 63.46 \\
GATA1 & 5'-GTAGCGGGAATTGTGGGGAGGTG-3' & 61.50 \\
& 5'-GGGAAAGGCATGAGGTGGCTAACA-3' & 61.41 \\
\hline
\end{tabular}

\section{Chromatin immunoprecipitation (ChIP)}

SH-SY5Y cells were treated with $0.2 \mu \mathrm{M}$ dPPA for $72 \mathrm{~h}$, and then, ChIP analysis was performed using ChIP assay kits (Beyotime) according to the manufacturer's recommendations with a CEBP $\beta$ antibody (Santa Cruz Biotechnology, sc-9314) and control IgG (Abcam). The input control DNA or immunoprecipitated DNA was then subjected to PCR amplification using primers specific to the furin promoter (forward primer 5'-ACCAGAGCCCAGCGTTCAGCAG-3' and reverse primer 5'-CATGGCCAGCCAGTGCTGCCA-3'). The PCR products were separated by $2 \%$ agarose gel electrophoresis and visualized with ethidium bromide staining.

\section{Cell viability assay}

Cell viability was assessed using a CCK-8 Cell Counting Kit (Vazyme). Briefly, cells were seeded into 96-well plates $\left(0.8-1.0 \times 10^{4}\right.$ cells per well) overnight and were then treated with DMSO (Control), PMA, PDBu, dPA or dPPA $(10 \mu \mathrm{M})$ for $72 \mathrm{~h} .10 \mu \mathrm{L}$ of the CCK-8 solution was then added to each well and absorbance was measured at $450 \mathrm{~nm}$ with a microplate reader (BioTek, Winooski, Vermont, USA) after incubation for another $4 \mathrm{~h}$. Each sample was carried out in triplicate, and the average optical density (OD) was used for calculation.

\section{Statistical analysis}

All data were shown as mean \pm SEM. Statistical analyses were performed with the Graphpad Prism software. Data were analyzed either by Student's unpaired $t$-test or one-way ANOVA followed by post hoc analysis. Differences were considered to be significant when $P<0.05$.

\section{Abbreviations}

$\mathrm{AD}$, Alzheimer disease; ADAM10, A disintegrin and metalloproteinase domain-containing protein 10; BDNF, Brain derived neurotrophic factor; СЕВP $\beta$, CCAAT/ enhancer-binding protein $\beta$; CNS, central nervous system; DNA, Deoxyribonucleic acid; dPA, 12-Deoxyphorbol 13-acetate; dPPA, 12-Deoxyphorbol 13-phenylacetate 20-acetate; ERK, extracellular regulated protein kinases; GATA1, GATA binding protein 1; NGF, Nerve growth factor; PCs, Proprotein convertases; PDBu, Phorbol 12, 13-dibutyrate; PI3K, Phosphoinositide 3-kinase; PKC, Protein kinase C; PMA, Phorbol 12-myristate 13-acetate; Smad2/7, mothers against DPP homolog2/7; TGF $\beta$, Transforming Growth Factor $\beta$.

\section{Author contributions}

GJ Chen designed research; JS Zha and BL Zhu performed research and analyzed data; L Liu, YJ Lai, Y Long, XT Hu, XJ Deng, XF Wang and Z Yan provided assistance in research; JS Zha, GJ Chen and BL Zhu wrote the paper.

\section{ACKNOWLEDGMENTS}

This study was supported by grants from National Natural Science Foundation of China (NO. 81171197 \& 81220108010).

\section{CONFLICTS OF INTEREST}

The authors declare no conflicts of interest.

\section{REFERENCES}

1. Seidah NG, Chretien M. Proprotein and prohormone convertases: a family of subtilases generating diverse bioactive polypeptides. Brain Res. 1999; 848:45-62. 
2. Rockwell NC, Krysan DJ, Komiyama T, Fuller RS. Precursor processing by kex2/furin proteases. Chem Rev. 2002; 102:4525-4548.

3. Nakayama K. Furin: a mammalian subtilisin/Kex2p-like endoprotease involved in processing of a wide variety of precursor proteins. Biochem J. 1997; 327:625-635.

4. Thomas G. Furin at the cutting edge: from protein traffic to embryogenesis and disease. Nat Rev Mol Cell Biol. 2002; 3:753-766.

5. Young JA, Collier RJ. Anthrax toxin: receptor binding, internalization, pore formation, and translocation. Annu Rev Biochem. 2007; 76:243-265.

6. Schroeder NE, Androwski RJ, Rashid A, Lee H, Lee J, Barr MM. Dauer-specific dendrite arborization in C. elegans is regulated by KPC-1/Furin. Curr Biol. 2013; 23:1527-1535.

7. Salzberg Y, Ramirez-Suarez NJ, Bulow HE. The proprotein convertase KPC-1/furin controls branching and selfavoidance of sensory dendrites in Caenorhabditis elegans. PLoS Genet. 2014; 10:e1004657.

8. Seidah NG, Benjannet S, Pareek S, Savaria D, Hamelin J, Goulet B, Laliberte J, Lazure C, Chretien M, Murphy RA. Cellular processing of the nerve growth factor precursor by the mammalian pro-protein convertases. Biochem J. 1996; 314:951-960.

9. Seidah NG, Benjannet S, Pareek S, Chretien M, Murphy RA. Cellular processing of the neurotrophin precursors of NT3 and BDNF by the mammalian proprotein convertases. FEBS Lett. 1996; 379:247-250.

10. Manni L, Rocco ML, Bianchi P, Soligo M, Guaragna M, Barbaro SP, Aloe L. Nerve growth factor: basic studies and possible therapeutic applications. Growth Factors. 2013; 31:115-122.

11. Lu B, Nagappan G, Guan X, Nathan PJ, Wren P. BDNFbased synaptic repair as a disease-modifying strategy for neurodegenerative diseases. Nat Rev Neurosci. 2013; 14:401-416.

12. Mizui $T$, Ishikawa $\mathrm{Y}$, Kumanogoh $\mathrm{H}$, Kojima $\mathrm{M}$. Neurobiological actions by three distinct subtypes of brainderived neurotrophic factor: multi-ligand model of growth factor signaling. Pharmacol Res. 2016; 105:93-98.

13. Tiveron C, Fasulo L, Capsoni S, Malerba F, Marinelli S, Paoletti F, Piccinin S, Scardigli R, Amato G, Brandi R, Capelli P, D’Aguanno S, Florenzano F, et al. ProNGF NGF imbalance triggers learning and memory deficits, neurodegeneration and spontaneous epileptic-like discharges in transgenic mice. Cell Death Differ. 2013; 20:1017-1030.

14. Adachi N, Numakawa T, Richards M, Nakajima S, Kunugi H. New insight in expression, transport, and secretion of brain-derived neurotrophic factor: implications in brainrelated diseases. World J Biol Chem. 2014; 5:409-428.

15. Lichtenthaler SF. alpha-secretase in Alzheimer's disease: molecular identity, regulation and therapeutic potential. J Neurochem. 2011; 116:10-21.
16. Anders A, Gilbert S, Garten W, Postina R, Fahrenholz F. Regulation of the alpha-secretase ADAM10 by its prodomain and proprotein convertases. FASEB J. 2001; 15:1837-1839.

17. Hwang EM, Kim SK, Sohn JH, Lee JY, Kim Y, Kim YS, Mook-Jung I. Furin is an endogenous regulator of alphasecretase associated APP processing. Biochem Biophys Res Commun. 2006; 349:654-659.

18. Lei RX, Shi H, Peng XM, Zhu YH, Cheng J, Chen GH. Influence of a single nucleotide polymorphism in the P1 promoter of the furin gene on transcription activity and hepatitis B virus infection. Hepatology. 2009; 50:763-771.

19. Wu-Zhang AX, Newton AC. Protein kinase C pharmacology: refining the toolbox. Biochem J. 2013; 452:195-209.

20. Nakagawa Y, Yanagita RC, Hamada N, Murakami A, Takahashi H, Saito N, Nagai H, Irie K. A simple analogue of tumor-promoting aplysiatoxin is an antineoplastic agent rather than a tumor promoter: development of a synthetically accessible protein kinase $\mathrm{C}$ activator with bryostatin-like activity. J Am Chem Soc. 2009; 131:7573-7579.

21. Miana GA, Riaz M, Shahzad-ul-Hussan S, Paracha RZ, Paracha UZ. Prostratin: an Overview. Mini Rev Med Chem. 2015; 15:1122-1130.

22. Burgess SK, Sahyoun N, Blanchard SG, LeVine H, 3rd, Chang KJ, Cuatrecasas P. Phorbol ester receptors and protein kinase $\mathrm{C}$ in primary neuronal cultures: development and stimulation of endogenous phosphorylation. J Cell Biol. 1986; 102:312-319.

23. Castagna M, Takai Y, Kaibuchi K, Sano K, Kikkawa U, Nishizuka Y. Direct activation of calcium-activated, phospholipid-dependent protein kinase by tumor-promoting phorbol esters. J Biol Chem. 1982; 257:7847-7851.

24. Wilkinson SE, Parker PJ, Nixon JS. Isoenzyme specificity of bisindolylmaleimides, selective inhibitors of protein kinase C. Biochem J. 1993; 294:335-337.

25. Kobayashi E, Nakano $H$, Morimoto M, Tamaoki $T$. Calphostin C (UCN-1028C), a novel microbial compound, is a highly potent and specific inhibitor of protein kinase $\mathrm{C}$. Biochem Biophys Res Commun. 1989; 159:548-553.

26. Ayoubi TA, Creemers JW, Roebroek AJ, Van de Ven WJ. Expression of the dibasic proprotein processing enzyme furin is directed by multiple promoters. J Biol Chem. 1994; 269:9298-9303.

27. Laprise MH, Grondin F, Cayer P, McDonald PP, Dubois CM. Furin gene (fur) regulation in differentiating human megakaryoblastic Dami cells: involvement of the proximal GATA recognition motif in the P1 promoter and impact on the maturation of furin substrates. Blood. 2002; 100:3578-3587.

28. Blanchette F, Rudd P, Grondin F, Attisano L, Dubois CM. Involvement of Smads in TGFbeta1-induced furin (fur) transcription. J Cell Physiol. 2001; 188:264-273.

29. Brose N, Betz A, Wegmeyer H. Divergent and convergent signaling by the diacylglycerol second messenger pathway in mammals. Curr Opin Neurobiol. 2004; 14:328-340. 
30. Tsukada J, Yoshida Y, Kominato Y, Auron PE. The CCAAT/ enhancer (C/EBP) family of basic-leucine zipper (bZIP) transcription factors is a multifaceted highly-regulated system for gene regulation. Cytokine. 2011; 54:6-19.

31. Huber R, Pietsch D, Panterodt T, Brand K. Regulation of C/ EBPbeta and resulting functions in cells of the monocytic lineage. Cell Signal. 2012; 24:1287-1296.

32. Chandran UR, DeFranco DB. Regulation of gonadotropinreleasing hormone gene transcription. Behav Brain Res. 1999; 105:29-36.

33. Sun W, Choe YS, Lee YJ, Kim K. Suppression of GnRH gene expression in GT1-1 hypothalamic neuronal cells: action of protein kinase C. Neuroreport. 1997; 8:3541-3546.

34. Luo LG, Wang S, Su E, Jackson IM. Evidence from studies with N-ethyl-maleimide and 12-O-tetradecanoylphorbol13-acetate that AP-1 and CREB are involved in the glucocorticoid activation of TRH gene expression in hypothalamic cultures. Brain Res. 1999; 841:189-192.

35. Hahm SH, Eiden LE. Cis-regulatory elements controlling basal and inducible VIP gene transcription. Ann N Y Acad Sci. 1998; 865:10-26.

36. Tran PL, Deugnier MA. Intracellular localization of 12-O-3$\mathrm{N}$-dansylamino TPA in $\mathrm{C} 3 \mathrm{H} / 10 \mathrm{~T} 1 / 2$ mouse cell line. Carcinogenesis. 1985; 6:433-439.

37. Slater SJ, Ho C, Stubbs CD. The use of fluorescent phorbol esters in studies of protein kinase C-membrane interactions. Chem Phys Lipids. 2002; 116:75-91.

38. Blumberg PM, Konig B, Sharkey NA, Leach KL, Jaken S, Jeng AY. Analysis of membrane and cytosolic phorbol ester receptors. IARC Sci Publ. 1984; :139-156.

39. Dar AC, Shokat KM. The evolution of protein kinase inhibitors from antagonists to agonists of cellular signaling. Annu Rev Biochem. 2011; 80:769-795.

40. Newton AC. Protein kinase C: structural and spatial regulation by phosphorylation, cofactors, and macromolecular interactions. Chem Rev. 2001; 101:2353-2364.

41. Ho C, Slater SJ, Stagliano BA, Stubbs CD. Conformation of the $\mathrm{C} 1$ phorbol-ester-binding domain participates in the activating conformational change of protein kinase $\mathrm{C}$. Biochem J. 1999; 344 Pt 2:451-460.

42. Mamidi N, Gorai S, Mukherjee R, Manna D. Development of diacyltetrol lipids as activators for the $\mathrm{C} 1$ domain of protein kinase C. Mol Biosyst. 2012; 8:1275-1285.

43. Dries DR, Newton AC. Kinetic analysis of the interaction of the $\mathrm{C} 1$ domain of protein kinase $\mathrm{C}$ with lipid membranes by stopped-flow spectroscopy. J Biol Chem. 2008; 283:7885-7893.

44. Zhang G, Kazanietz MG, Blumberg PM, Hurley JH. Crystal structure of the cys2 activator-binding domain of protein kinase C delta in complex with phorbol ester. Cell. 1995; 81:917-924.

45. Ananthanarayanan B, Stahelin RV, Digman MA, Cho W. Activation mechanisms of conventional protein kinase
$\mathrm{C}$ isoforms are determined by the ligand affinity and conformational flexibility of their $\mathrm{C} 1$ domains. J Biol Chem. 2003; 278:46886-46894.

46. McMahon S, Grondin F, McDonald PP, Richard DE, Dubois CM. Hypoxia-enhanced expression of the proprotein convertase furin is mediated by hypoxia-inducible factor-1: impact on the bioactivation of proproteins. J Biol Chem. 2005; 280:6561-6569.

47. Zhou Z, Wang R, Yang X, Lu XY, Zhang Q, Wang YL, Wang H, Zhu C, Lin HY, Wang H. The cAMP-responsive element binding protein (CREB) transcription factor regulates furin expression during human trophoblast syncytialization. Placenta. 2014; 35:907-918.

48. Gendron FP, Mongrain S, Laprise P, McMahon S, Dubois CM, Blais M, Asselin C, Rivard N. The CDX2 transcription factor regulates furin expression during intestinal epithelial cell differentiation. Am J Physiol Gastrointest Liver Physiol. 2006; 290:G310-318.

49. Blanchette F, Day R, Dong W, Laprise MH, Dubois CM. TGFbeta1 regulates gene expression of its own converting enzyme furin. J Clin Invest. 1997; 99:1974-1983.

50. Kazanietz MG. Novel "nonkinase" phorbol ester receptors: the C1 domain connection. Mol Pharmacol. 2002; 61:759-767.

51. Wang QJ. PKD at the crossroads of DAG and PKC signaling. Trends Pharmacol Sci. 2006; 27:317-323.

52. Lallemend F, Hadjab S, Hans G, Moonen G, Lefebvre PP, Malgrange B. Activation of protein kinase CbetaI constitutes a new neurotrophic pathway for deafferented spiral ganglion neurons. J Cell Sci. 2005; 118:4511-4525.

53. Zeng C, Wang W, Yu X, Yang L, Chen S, Li Y. Pathways related to PMA-differentiated THP1 human monocytic leukemia cells revealed by RNA-Seq. Sci China Life Sci. 2015; 58:1282-1287.

54. Kavarthapu R, Dufau ML. Role of EGF/ERBB1 in the transcriptional regulation of the prolactin receptor independent of estrogen and prolactin in breast cancer cells. Oncotarget. 2016; 7:65602-13. https://doi.org/10.18632/ oncotarget.11579.

55. Lu YC, Kim I, Lye E, Shen F, Suzuki N, Suzuki S, Gerondakis S, Akira S, Gaffen SL, Yeh WC, Ohashi PS. Differential role for $\mathrm{c}-\mathrm{Rel}$ and $\mathrm{C} / \mathrm{EBPbeta} /$ delta in TLR-mediated induction of proinflammatory cytokines. J Immunol. 2009; 182:7212-7221.

56. Tanaka T, Yoshida N, Kishimoto T, Akira S. Defective adipocyte differentiation in mice lacking the C/EBPbeta and/or C/EBPdelta gene. EMBO J. 1997; 16:7432-7443.

57. Chumakov AM, Silla A, Williamson EA, Koeffler HP. Modulation of DNA binding properties of CCAAT/enhancer binding protein epsilon by heterodimer formation and interactions with NFkappaB pathway. Blood. 2007; 109:4209-4219.

58. Ross SE, Radomska HS, Wu B, Zhang P, Winnay JN, Bajnok L, Wright WS, Schaufele F, Tenen DG, MacDougald OA. Phosphorylation of C/EBPalpha inhibits granulopoiesis. Mol Cell Biol. 2004; 24:675-686. 
59. Corre S, Primot A, Baron Y, Le Seyec J, Goding C, Galibert MD. Target gene specificity of USF-1 is directed via p38mediated phosphorylation-dependent acetylation. J Biol Chem. 2009; 284:18851-18862.

60. Hu XT, Zhu BL, Zhao LG, Wang JW, Liu L, Lai YJ, He L, Deng XJ, Chen GJ. Histone deacetylase inhibitor apicidin increases expression of the alpha-secretase ADAM10 through transcription factor USF1-mediated mechanisms. FASEB J. 2017; 31:1482-1493. 